\title{
Profit And Risk for Property Business Using Sharia and Conventional System: A Comparative Analysis
}

\author{
DOI: https://doi.org/10.18196/afkaruna.v17i1.11325
}

\section{ZAINI MUCHLIS}

Department of Economics, Faculty of Economics and Business Universitas Muhammadiyah Yogyakarta

E-mail: zaini.muchlis@umy.ac.id

\section{AYIF FATHURRAHMAN}

Department of Economics, Faculty of Economics and Business Universitas Muhammadiyah Yogyakarta

E-mail: ayif.fathurrahman@umy.ac.id

\begin{abstract}
Sharia and conventional business management system are often become a parameter in gaining profit and managing the risk faced by the entrepreneurs. This research aims to determine the comparison of profit and risk obtained by the property entrepreneurs in conducting their business when they use conventional or sharia system. This research is qualitative descriptive analysis. The variables that would be investigated are the profit obtained by the property business owner and the risks in conducting this business when the business owner uses sharia and conventional system in the capital investment or the buying and selling process of a certain property unit. The data was collected through an interview and documents. The article shows that conventional and sharia are a concept or system that generally used by the entrepreneurs in conducting their business to obtain the profit and face the risks. Both of the systems have advantages and disadvantages. This article further argues that sharia system gives a higher profit and fewer risks rather than the conventional system. It is because in the sharia system, entrepreneurs or costumers are not concerned about the burden of the interest and fines of the debt from a financing institution. Although there are risks considered such as bad credit and longtime cash flow, the profit obtained through the sharia system is higher than the conventional one.

Keywords: Property business; Profit and risk; Sharia and conventional
\end{abstract}




\section{ABSTRAK}

Sistem manajemen bisnis syariah dan konvensional seringkali menjadi parameter dalam memperoleh keuntungan dan pengelolan risiko yang dihadapi oleh para pengusaha. Penelitian ini bertujuan untuk mengetahui perbandingan keuntungan dan risiko yang diperoleh pengusaha properti dalam menjalankan usahanya baik secara konvensional maupun syariah. Jenis penelitian yang digunakan adalah analisis deskriptif kualitatif, adapun variabel yang akan diteliti meliputi keuntungan yang akan didapat pengusaha property serta resiko yang dihadapinya dalam menjalankan usaha ini, baik yang berkaitan dengan hal permodalan ataupun dalam proses jual beli unitnya ketika menggunakan system syariah dan konvensional. Metode pengumpulan data menggunakan wawancara, angket dan dokumentasi lapangan, yaitu berupa daftar pertanyaan-pertanyaan yang mengungkap variabel dan rubrik refleksi diri. konvensional dan syariah merupakan sebuah konsep/system yang harus dipilih oleh pelaku usaha dalam menjalankan bisnisnya dalam mendapatkan keuntungan dan menghadapi resiko dalam usahanya. Keduanya memiliki kelebihan dan kekurangan, adapun system syariah dapat memberikan keuntungan yang lebih besar dan juga resiko yang lebih kecil jika dibandingkan dengan system konvensional. Hal tersebut dikarenakan dalam system syariah baik pengusaha ataupun konsumen tidak dikhawatirkan menanggung beban bunga dan denda yang dihasilkan dari hutang terhadap lembaga pembiayaan. Meskipun ada resiko lain yang ditanggungnya seperti adanya kredit macet dan cash flow yang relative lama, akan tetapi keuntungan yang didapat melalui system syariah akan jauh lebih besar.

Keywords: Bisnis properti; Keuntungan dan resiko; Syariah dan konvensional

\section{INTRODUCTION}

Property is a primary need for society, so that the property business becomes one of the promising businesses in gaining profit for entrepreneurs in their field. Indonesia is the largest Muslim country in the world. Nowadays, most of Indonesian people who are Muslim and non-Muslim still follow the conventional economy and make it as guide to their economic activities. Moreover, some Muslims do not want to apply the Islamic economy as their guide in economic activities because most of them do not know the concept of sharia economy. In the concept of the conventional economy, many disadvantages which can be very detrimental to those involved in it. Besides, the objectives of the conventional economy also give a detriment or even misery. Rather than bringing welfare, instead it makes "the rich are richer, and the poor are getting poorer" and it is very ironic. ${ }^{1}$

Sharia economic system, which is now present and touches the Indonesian society, gives the fresh air for the people especially property entrepreneurs who yearn for justice and welfare. They can develop their business and 
achieve more profit when applying the concept of sharia economy. Besides, they can gain a bigger profit. The concept also brings a blessing for their wealth. The concept of economy in the Islamic perspective is a demand for life as well as the suggestion with the dimension of worship. Likewise, the conventional economy often ignores the moral and ethical of the transaction and only focus on the profit without thinking of the consequences in the hereafter.

House is one of the basic needs of a human being to be fulfilled. Having a house is a hope of all people and even it becomes a primary need for the married couple. The number of such needs make the development of property investment increases and becomes a favorite for society and investors who will invest in it. The development of the sharia system is also coloring the property investment world, characterized by a growing number of appearances of sharia property. Moreover, there is a type of Home Loan (KPR) that become a trend in society now to buy the sharia home. Sharia KPR or home loan adapts the sharia system of selling and buying which is free of interest and riba, and because it is not related to the bank. ${ }^{2}$

An entrepreneur definitely will determine the profit and risks incurred when he handles a business. In this case, a property entrepreneur will see an opportunity offered by either sharia or conventional system, so that he will compare them by determining the profit and risks. By looking at those systems, there are advantages and disadvantages especially those which are related to the profit and risks, borne by an entrepreneur. Therefore, the researcher wants to identify the differences between those two systems deeply, whether on the profit or the risks, so that the Muslim entrepreneurs can apply the best system for them in the future. As a Muslim entrepreneur, he should be able to see the plus and minus offered from both systems by determining the worldly and hereafter aspects, and then he can get a big fortunate both in the world and hereafter.

Due to the background above, the researcher identifies the problems which are:

1. Business property or selling a house is a business that sells the primary needs in society, it is necessary to find out the role model of the buying and selling system which is studied empirically and scientifically from the treasures of Islamic economic though.

2. In the Islamic economic discourse, profit and loss sharing is a system that is accepted as a financing system, because it is closer to the principle of 
justice in economic transactions.

3. The risks in business become a consideration that is critical for the entrepreneur. It needs an explanation of the risks incurred from conducting business by using sharia or conventional system.

\section{LITERATURE REVIEW}

\section{A. Review of Property Business}

Property business nowadays becomes a trend in the investment field and the most interested by many people. While, it has a great profit, this business is also assessed to have a low risks, so it makes this business become the most favored by entrepreneurs. Many people assesses that the property business today as an investment that has a very wide market share. So that people or entrepreneurs whether they beginner or expert are competing in investing on this business. Although the investment of property is known by the great profit, but business is not always running smoothly. Property business can fail, so the risk of this business is also necessary to be noticed. Therefore, a property investor needs to know about the advantages and risks of business property.

The definition of property is goods and all things legally in a status owned by a person or legal entity. Property can be divided into two kinds which are personal property and real property. Personal property is any kind of property that can be moved and not attached to the ground or become a unit with buildings, such as equipment, furniture, vehicles, and others. Whereas the real property is a proprietary right based on the legal interest that is inherent on the real estate or legal relationship of juridical by the owner of real estate such as land and building. ${ }^{3}$

The house is a primary need for the human being, so that many people need it. Then, the property business can move the whole sectors such as building materials industry, heavy equipment, consultants, banking, insurance, and labor services, so that is not only developer, contractor, or costumer who can get the benefit from this business. People who do the business property is called investor property, they buy then they sell a product which is property whether it is new or secondhand, so that they get the profit from the activity such as rent or result from the sale of property. An investor in property field should know more about this business, the deep knowledge about this business property is important and useful for increasing the value of the invested property and it also anticipate the loss of this business. 


\section{B. The Benefits of Business Property}

Business property has many benefits and advantages that many people do not know about it, even this benefit can be very promising. The examples of benefits that can be reached from this business are:

1. Added Value

Added value in this context means property is built over a plot of vacant land, and then the value of that place is increasing, especially if the position or the layout of the building is very strategic for the example in the center of the city or near from public facilities such as offices or shopping center, the value will be more expensive.

2. Income Appreciation (Profit continuously increasing every year). Having a plot of vacant land, house, or office will make a big profit. Why? Because every year, the value or price of land or building is continuously increasing, for example if we buy a vacant land now, the value of land will increase after two or three years. The number of people is continuously increasing but the land is not increase, so it is normal if the land price continuously increases significantly every year.

3. Not effected by inflation.

Many people go in the property investment field because in addition to the price which is continuously increasing every year, investment business is also insusceptible from the inflation. People are sure by buying a property, the value will not go down but it will continuously increase differently from the currency business (foreign currency) that the value is very influenced by inflation.

4. Property has a wide and promising market.

The number of people is continuously increasing but the land is not increase so that many people who need the residence, so it normally if the price of land especially in the urban areas is continuously increasing.

5. Property has a long-term investment.

When compared with other investment products such as gold, deposits, and others, the property is durable investment product. In 3-5 years, the value of developed property can obtain capital gain (profit from difference between the purchase price and the sale price).

\section{The Risks of Business Property}

Basically, conducting something certainly has some risks to face in which those risks are the impact of what we done. The risks that can interfere with 
the activities of the business usually occur due to several factors which are internal and external factors. The internal factor of the business risks arises from the internal business for example it related to ineffective marketing activities. Whereas, the external factor arises from the external business for example it related to changes of demands for goods or services produced by a company. ${ }^{4}$ The risks that should be faced by property entrepreneurs are:

1. Requires Large Capital

Basically, almost the entire businesses need a capital and asset especially property business. The nature of property business investment is capital intensive. Business property can be called as a business that needs a large capital because the result of this business is also great. In conducting business property should spend a lot of additional costs such as tax or PPH which is charged to the seller and BPHTB which is charged to the customer. So that the risks of business property about the capital is something needs to be noticed and considered because if we are not careful then the spent capital may not bring the suitable profit or even can lose.

2. The Risks of Sales Time

One of the types of business risks property is the time for sale the units, its takes a long time to be sold out. It is because a person who wants to buy the property is not easy to find. Then, as the entrepreneur of business property should understand the risks of this business and should be patient to do the marketing and sales.

3. Risks of Natural Disasters

This natural disaster cannot be avoided and can befall to anyone that can bring the big risk for business property, whether it is earthquake, avalanche, flood, or tsunami. The built property can be destroyed by natural disasters. This is the risk that the property manager should bear. If we look at the profit and the risks obtained by the property entrepreneur in the review above, it all refers to something global that is always experienced by the entrepreneurs, and the explanation above have not discussed about the profit and the risks of a transaction mechanism conducted by property entrepreneurs. Whereas, through that transaction the entrepreneur gains the real profit and also knows the risks that will be faced, because all of that related to the business capital and also the concept of buying and selling that will be conducted. Then through this research, the researcher wants to explain about the mechanism of transaction management and marketing property through conventional and sharia system, in which the 
property entrepreneur can compare the advantages and disadvantages of those two systems, so that they can understand clearly about the gained profit and also ready to face the risks in the implementation of the business.

\section{RESEARCH METHOD}

The object of the study that is intended in this research is the businessperson who have been conducting the business in property that then gained the profit and also faced the certain risks in conducting the business, whether it is conducted by sharia or conventional system. The population of this research is the property business, whether who use sharia or conventional system. The data in this study were taken from six property companies that run their business with both systems. ${ }^{5}$ The informants in this study consisted of company leaders and eighty-two staff who run this company with various positions. The type of this research is descriptive analysis. The variables that will be examined are the profit gained and also the risks faced by the property business in term of capital and buying and selling of the products when it uses sharia and conventional system. Data collection method is through the interview, questionnaire, and field documentation which are the list of the questions that reveals the variables and self-reflection rubric. The technic of analysis data used the content validity and data triangulation, verification, and FGD (Focused Discussion Group).

\section{DISCUSSION}

\section{A. Overview of capital management and transaction of}

\section{buying and selling property}

In conducting a business property, an entrepreneur will faced a variety of issues whether in licensing, construction, taxes and the things related to finance. The finance is a biggest obstacle for an entrepreneur in this business because there are many things in this business that needs a big cost especially for licensing, construction, and buying and selling of the property. Hence, the capital and the concept of sale should be prepared well so that the business does not cease in middle of process. Financing companies such as banks, BMT, leasing, cooperatives etc. are often needed by those who conduct the business with conventional system to support the business. Besides, those who use sharia system will seek the partner to cooperate in finding a business 
capital, whether it cooperation with individual who have sufficient capital or to the institution labeled sharia.

On the other hand, the transaction of marketing and sale done in buying and selling of property also has various ways and the process often confuses the people who first time buys a house. Therefore, it is necessary to know about the payment procedures of the property that can be done by costumers. According to Fikri as the owner of Kirana Garden property: There are advantages and disadvantages in the implementation of the process of buying and selling the property and it depends on the financial capability of the costumers. There are three ways to buy and sell the property:

\section{Hard Cash}

In this system, the costumers buy the property in cash on the beginning. Usually, the payment system with hard cash is done at least a month since the agreement between the costumer and seller. For the customers who have a large budget is recommended to buy by this system because it has a big profit in which the seller usually will give a big discount of the property price about $10 \%$ to $15 \%$ of the total price. In addition to get a great discount, the customers also do not to worry with the monthly installments because it is paid off. Besides, they do not to worry about the fluctuations in bank rates that are often increasing as in the credit system. ${ }^{6}$

\section{Cash Installment}

The payment system with cash installment is done by paying the property gradually with a limited period of time in which the deadline is agreed by both parties. Usually, a period of the payment with this cash installment method occurs within six months to a year with an excess of payment that has been set by the seller. Due to the limited period of payment, so the customers are obligated to pay the deposit about 30\% to $50 \%$ of the selling price to the seller and also the substantial monthly installment fee. If we look at this system, there are some advantages and disadvantages:

a. The advantages.

1. Still get a discount even though not as big as the hard cash.

2. Not so hassle with the administration because the installment can be paid to the seller directly and not to the third party (Bank/Leasing/ Other financial institution).

3. Not so long to bear a debt with $0 \%$ installment rate.

b. The disadvantages. 
1. The value of the installment is large because of the short period of time

2. If we meet a shifty seller, the potential legal risk is greater than the hard cash payment.

The illustration of installment cash:

For example the price of a unit of house is 400 million, in the beginning of buying and selling agreement the customer pay the down payment about 10 million, then he pay the deposit about $50 \%$ of the total price of the house purchased, subtracted by down payment that has been paid (IDR 200 million -10 million $=190$ million). The remaining payment of 200 million will be charged for 1 year.

\section{Home Loan or KPR}

In this payment system, the costumers involve the third party in the payment activity such as Bank, Leasing, Cooperative, or other financial institutions. The funding by home loan system makes the bank paid the acquittance of the house to the seller, then the customer will pay the installment to the bank with certain interest rate. However, need to be noted that the bank will be paid the house no more than $70 \%-80 \%$ of the house price according to the result of credit feasibility analysis, and the remaining of $20 \%-30 \%$ is the down payment that should be paid by the customer to the seller. The range of tenor is varies between 3-15 years. In the home loan payment system, there are some advantages and disadvantages such as:

\section{a. Advantages.}

1. It does not require a great capital, the costumer only need to pay the down payment and deposit to the seller.

2. The buying and selling has been completed by life insurance and wildfire.

3. The minimum of legal risks, it is because the bank will check the entire document of house ownership and IMB. Moreover, if occur the legal problems, the bank will go ahead as the involved party for the house.

b. Disadvantages.

1. The price of the house will more expensive because it is added by the interest, plus the cost of credit administration and contract provisions charged by the bank.

2. It will quite complicated by completing the documents requirement 
for a credit application.

3. It creates the obligation to pay a debt for long term period.

Illustration of Home Loan payment

The price of Mr. Onis' house is 500 million, in the agreement of buying and selling the costumer pay the down payment about 10 million. Then, he pay the deposit about $30 \%$ of the total price of house purchased, subtracted by the paid down payment which is (150 million -10 million $=140$ ). The remaining payment of 350 million will be paid by installment during the period agreed by both parties and also added by the interest rate.

Generally, the payment system occurred in the buying and selling transaction of property has been done through some ways as mentioned above. Surely, those ways have some advantages and disadvantages for the entrepreneur that will impact the profit gained and the risks that will be faced. Therefore, as the entrepreneur they should be careful in making decision because it will bring the impact on the result of the business.

\section{B. Mechanism of Conventional and Sharia System}

Generally, both systems are not very different, but if we see in detail to the business management agreement of those systems, it will appear the significant differences and also it will look different on the mechanism of the conducted business. The differences can be found on the capital and the concept of buying and selling implemented. In the capital, the entrepreneurs who are apply the conventional system often begin the business with the capital from the debt to bank, leasing, cooperative, or other financial institutions. Loan venture capital obtained from the financial institution obligates the creditor to deliver the collateral of valuable thing to the debtor, in which obligates the creditor to pay the installment loan with the interest to the debtor, in addition to the fine that should be bear if there is lateness in paying the installment. ${ }^{7}$

Besides, the venture capital obtained through the sharia system, the entrepreneur get it through the cooperation by profit sharing system with the third party which is an investor, whether an individual investor, sharia bank, or other financial sharia institutions. An investor can help to supply the entire needs of the venture capital by not loan but by conducting the partnership relation with the entrepreneur, in which the investor as the funder or shahibul maal and the entrepreneur as mudharib. This cooperation financing system in 
Islam is called mudharabah/ trust financing. ${ }^{8}$ This cooperation can be conducted in the certain period, and the profit sharing between both parties is divided periodically with an agreement. On the due date, the entrepreneur returns the amount of fund to the investor and also the profit sharing that has not be divided. Necessary to be noticed, that in this cooperation, both parties should be ready to bear the loss together and this is the difference from the conventional system.

In the buying and selling process, the mechanism conducted by conventional system is different from sharia system. The transaction between the costumer and seller in the conventional system can be conducted by cash and credit, whether cash installment or home loan. The basic differences between those systems are occurred on the transaction process. The conventional credit makes its money as an object of business transaction, when the object transacted is money then there are interest and fine because the nature of the basic buying and selling in that system is loan from the third party. When it is a loan, then it is obligated for the costumer to pay the loan to the funder party (financial institution) with the interest. For example, the costumer wants to buy a house with the price of 500 million, bank will give the loan to the costumer with a requirement that he should give the collateral to the bank for the loan. Since the fund accepted by the costumer, he will pay the loan by installment with the certain period that has been agreed by both parties and also he should pay the added margin for $5-10 \%$ of the loan. The benefit of this concept is the costumer can return the loan with the long time period which is $5-25$ years.

On the other hand, the object sold in the sharia system is a good (its property). So that there is no interest or fine in the transaction process because the basic or buying and selling is not the loan but the barter. The main features that distinguish the Islamic system from the conventional are the prohibition of interest (riba) on loans and excessive leverage, focus on profit sharing and dependence on economic transactions involving tangible assets. ${ }^{9}$ Mechanism of buying and selling implementation by the sharia concept can be conducted by two ways: first, the costumer can buy the property on cash to the seller or can buy it on credit by doing the transaction of installment directly according to the agreement of price and tenor that has been determined by both parties. The process of transaction is conducted on the short period which is 5-15 years and only involves the costumer and seller without any third party such as bank, leasing, or other financial institution. Second, in 
this sharia credit system the costumer can involve the third party in the buying activity, in which in the transaction the sharia bank/ sharia financial institution (third party) will buy the house from the developer suitable with the costumers' wishes on cash then sell it to the costumer by credit with no interest, but the bank takes the profit margin from the sale price of that house. In Islam, this system is known as murobahah. ${ }^{10}$ The example of this concept is: costumer wants to buy a house with a price of 500 million the sharia bank will buy that house from the developer then sell it to the costumer with a price of 650 million by the tenor of 20 years (the sharia bank takes the profit margin about 150 million during tenor). Then, the costumer should pay installment for 20 years with amount of 650 million without any interest and fine if there is lateness in paying the installment.

As the explanation of both system mechanisms above, we got some points of differences between them which are:

1. In conventional system:

- Money is an object of transaction in conventional system

- The capital is the result of loan from the third party

- Requirements and provisions of capital loan/ buying and selling is determined by the third party as the debtor

- There is an interest rate that should be paid by the creditor to the third party

- There is a fine if the costumer late or in arrears in paying the instalment

- The tenor is about $5-25$ years

2. In sharia system

- The goods (house) are an object of transaction in the sharia system

- The capital is obtained from from the result of cooperation/partnership mudharabah

- Use the principle of Murabahah (profit sharing) agreement in the buying and selling

- There is no interest system

- There is no fine if occurs the lateness and arrears in installment payment

- The tenor is about $5-15$ years

\section{The Benefits and Risks of Conventional System}

Financing through the conventional credit is conducted based on the banking operational standard determined by government and comply with the 
legal rule in Indonesia. This is managed by government through the financial institutions and other parties who is involved in this case. So that will bring the profit and risks for the creditor or debtor who conducts the business and the transaction through this system. The profits of property entrepreneur if he conducts the transaction using the conventional system are:

1. Easy to get the financing capital.

The venture capital becomes the issue that often befalls to an entrepreneur in conducting the business, especially for those who wants to start a business. By the existence of financing concept through banking or other financial institutions makes the entrepreneur easier to get the venture capital and rolling the wheel of their business. This is because the entrepreneur can allocate the fund and budget of their business freely, so that the project can run as planned.

2. Have the low interest rate in financing.

The interest rate is something often calculated for the entrepreneurs or the creditor who wants to get the fund from the financing institution. Each institution usually has the different interest rate between one to other. If compared between conventional and baking and sharia banking, then the conventional bank has a lower interest rate, in which the average of conventional bank has a rate about 6\%-10\%every years. ${ }^{11}$ Besides, the sharia bank has a concept of financing capital and sales that is determined in the beginning of the transaction agreement, but if calculates the costs that should be paid by the creditor in paying the installment, we will found that sharia bank has the higher level of financing.

3. Cashflow/ the capital is returned relatively fast.

Each property entrepreneur will seek to get a quick refund of their business capital. It is a human nature that cannot be denied by everyone. Conventional system promises the property entrepreneurs to be able to get their business capital quickly through buy and sell transactions. This is because in buying and selling property transactions, the bank/ financing institution will pay directly the total cost of selling property that has been sold to the developer/seller. So the developer does not need to wait so long to get profit of the buying and selling the property in spite of it is done in credit.

4. Be able to manage and replace the result of business quickly.

The buying and selling by conventional system makes the property entrepreneur get the profit of their business quickly because the financing insti- 
tutions provide the result of the buying and selling transaction between the seller and costumer in cash to the developer, therefore the developer can replace the profit of the business for the next project without need to wait the returning of their capital.

5. Provides the insurance when occur the natural disasters.

The insurance is one of the unforgotten aspects for the property entrepreneur because the human does not know their fate of the natural disaster. Hence, insurance is the right solution for anticipating a disaster, so that the entrepreneur does not bear a loss when the disaster affects the damage on their property. Therefore, it is useful for the entrepreneur if he does not need to spend money for the renovation of the damaged property because of natural disasters.

In every way there must be a consequence as well as in a business there is profit and loss that is the phenomenon that occurs in this life. In entrepreneurship journey there is a risk that should be faced by the entrepreneur which is no exception to business property. The risks faced by the property entrepreneurs who apply conventional system are:

1. Overly complicated loan application

The process of loan application conducted by entrepreneurs for the venture capital or costumers in purchasing a unit of property to financial institutions often finds the troublesome constraints because there are many procedures conducted by the institution to help the costumer to get the funding that very complicated such as the customer should pass a business feasibility check, survey location, or also requires an equal collateral to the proposed capital loan, etc. It all makes the customers should be more prepared all the requirements that sometimes make him depressed in fulfilling it.

\section{An interest that should be paid}

The interest is a must be paid by the entrepreneur or the consumer to a third party/financing institution if they conduct the transaction by conventional system. Although the interest rate is not really high, but it becomes a big risk if the sale of unit property is stagnated. If they are as the costumers who conduct the credit to the financial institution, it also becomes a big risk when they are not able to pay off the purchase of property within certain period. Finally, they will have a debt that cannot be resolved except by auction the goods that they give as collateral to the 
lender.

3. The fine that should be paid if late to pay the installments.

Fines become a risk that should be considered if an entrepreneur started his business with debt, so does the consumer who bought the property unit through loan/credit to the financing institutions. In capital or purchase of the unit property by the conventional system has a trap for the debtor which is a fine for those who late in their debt/ loan payment. If someone has already stuck in the debt, it often leads to a loss in paying a fine because he is not able to continue the installment of the goods he credits. This is a big risk because there are many customers are caught up with a fine that culminated by foreclosure the property they owned.

4. Violate the Islamic sharia that affect to the blessing of the business. Entrepreneurs or consumers who do transactions through conventional systems often contradict the Islamic teachings because in that transaction there are some things that have been forbidden by Allah SWT. The forbidden thing is the existence of riba that is forbidden in Islam. Riba is the great sin in Islam, so that by the existence of riba in the transaction will makes unblessed of the business and the wealth.

\section{The Benefits and Risks of Sharia System}

The concept of the sharia funding is it can be conducted in both short or long term period for the entrepreneurs who need the added venture capital that is based on the principles of sharia. It is also for the customers who need the financing of the purchase an item. In this case, the concept of the financing usually used for the capital, payment of the production cost, purchase of materials, trade of the goods and services, contraction project, and many others. Hence, if we look generally to this sharia financing system, there are some benefits such as:

1. The transparence agreement

When apply an agreement about the financing either capital or loan, the debtor will sign the contract of agreement. In this sharia system, the transaction of the agreement will be transparence which is the debtor know the costs included in the agreement and he can negotiate the profit margin for the financing institution if he feel objected.

2. The bigger profit by added margin from the sale price of goods.

Scheme of murabahah in sharia system makes the property entrepreneur gets more profit from the sale of unit. Although the profit gained takes 
the longer period than the conventional system but the result obtained is greater. It is because the developer will get the profit from the costs of goods sold plus the profit margin from the financing agreement in credit. For example if the costumer buy a unit of house with the price of 500 million, then when he bought it by credit, the developer will increase the house's selling price to 600 million (depending on the duration of the credit and the agreement of both parties).

3. Do not pay the interest to the third party.

The capital needed by the entrepreneurs to run the project does not bring any concern on interest payments, because the principle of the agreement between entrepreneurs and financing institutions is cooperation. Likewise, in buying and selling that is conducted by costumers through Sharia systems, make costumers safer because there is no additional cost except the things that has been agreed by both parties in the beginning of buying and selling agreement.

4. There is no risk of fine that should be paid.

The agreement of sharia system is the agreement for cooperation and profit sharing, so in this case there is no risk of any fine that should be bear by the entrepreneur or costumer in conducting the transaction related to the capital or buying and selling. It is because the risk of fine will rise in the debt transaction, but the sharia system is not based on the debt/ loan agreement.

5. The blessing in the business and the result It has been the principle of Muslims to seek the blessing in life especially the blessing in obtaining the wealth that becomes a living for him and his family. By choosing the sharia system in every business and transaction, it will indirectly bring the blessing in every business outcome. It is because of his obedience in upholding Islamic sharia so that it makes Allah SWT bless him and eventually it will affect the blessing of all result of his works.

On the other hand, in conducting the business by sharia system also have some risks that should be faced by the property entrepreneur:

1. Difficult to get a capital.

A capital is an important thing in conducting a business, without it the business cannot be run. Sharia system is based on the cooperation in a business, then the obstacle to apply this system is difficult to get a trust of 
the party invited to cooperate, whether from the individual investor or financing institutions such as sharia bank, BMT, etc. The cause of this difficulty is the entrepreneur has not a clear concept of the business, so it makes a doubt on the partner in doing cooperation. The solution for this problem is by creating the clear proposal about the concept of the business that will be started whether on the cooperation agreement, profit sharing, procedure, business governance, and the others.

2. Cash flow/ capital return relatively longer

Cash flow by sharia system takes a relatively long time, moreover if a property is sold by credit. In this case, the entrepreneur can give a rule in the credit agreement that will be held with the costumer which is by giving a certain limitation of time for the payment. Therefore, it can shorten the time to returning the venture capital. Besides, this agreement is more profitable for the entrepreneur in the buying and selling transaction because he got the added profit margin from the result of buying and selling the property by credit.

3. Bad credit or the lateness on payment of monthly installment The costumer who is not able to continue the payment of credit installment is an obstacle that often occurs, and it becomes a risk that should be faced by the entrepreneur in buying and selling transaction of his property. This problem has a non-complicated solution because the prices of the property will continuously increasing. In this case, the entrepreneur can give a chance to the owner of that house to sell it then the result of sale can be used for paying the debt of house purchase. ${ }^{12}$ Moreover, the owner will get the profit from the sale of the house. In this case, each party will get a win solution for this problem.

4. Bear a risk on the nature disaster.

Sharia system has its own specificity in bearing a risk, in which the profit shared and loss borne together. Thus, if the loss is not from the negligence or maintainers, all losses are borne together between investors who lose capital and managers who lose energy, time and others. However, on the contrary if the loss is caused by the negligence or maintainer, he should repay and pay the capital back to the investor. ${ }^{13}$

A nature disaster is an unpredictable disaster, so in this case it is not a negligence of the entrepreneur in conducting the business. Then, if it occurs the loss will be borne together and not only for the entrepreneur. 


\section{CONCLUSION}

The profit and loss are something different that becomes a challenge for each business owner. Both of them are inevitable in the business field. On the other hand, conventional and sharia is a concept/system that must be chosen by them in conducting their business. This research limits the problem on the benefit gained by the entrepreneur of sharia and conventional property as well as the risks that will be incurred in conducting the business, especially in the capital and buying or selling of the product by using sharia and conventional system. Based on the benefits and risks faced by the property business above, it can be seen that the sharia system can provide a greater profit and also a smaller risk. This is because in the sharia system, whether businesspersons or costumers are not concerned about the burden of interest and fines resulting from debt to financing institutions. Although there are other risks borne such as a bad credit and a relatively long cashflow, but the profit margins gained through the sharia system will be greater.

\section{ENDNOTES}

1 Dwi Condro Triono, (2017) Ekonomi Pasar Syariah, Yogyakarta: Irtikaz.

2 Rosyid Aziz, (2015) Berkah Melimpah Dengan Bisnis Property Syariah, Bogor: AlAzhar Freshzone.

3 Roby Agung Kusuma, (2017) Untung Maksimal Dari Bisnis Properti, Jakarta: Laksana.

4 NM.Wahyu Kuncoro, (2015) 97 risiko Transaksi Jual Beli Properti, Jakarta: Raih asa Sukses.

5 The names of the companies in this study are Kirana Garden, Zafilla property, Hudaya Anugrah Madani, Basmalah property, Mitra Artha and Arkana Property.

6 Malte Kueger \& Seits Franz. (2017) Costs and benefits of cash and cashless payment instruments Module 2: The benefits of cash. e-book by Fritz Knapp Verlag, Frankfurt.

7 Umar Vadillo, (2005) Bank Tetap Haram: Kritik Terhadap Kapitalisme Sosialisme, dan Perbankan Syariah, Petaling Jaya: Pustaka Zaman.

8 Wahbah Al-Zuhaili, (2003) Al-Figh Al-Islam wa Adillathu, Damascus: Dar-Al fikr,

9 Chamberlain, T., Hidayat, S., \& Khokhar, A. R. (2020). Credit risk in Islamic banking: Evidence from the GCC. Journal of Islamic Accounting and Business Research.

10 P Wulandari, Putri, N. I. S. P., Kassim, S., \& Sulung, L. A, (2016) Contract Agreement Model for Murabahah Financing in Indonesia Islamic Banking. International Journal of Islamic and Middle Eastern Finance and Management. Vol. 9(2): 190-204. 
11 Https://www.rumah.com/panduan-properti/ Lima bank kpr dengan suku bunga rendah per januari 2019-2-9574.

12 Ahmad bin abdurrozaq Ad Duwaisy, (2011) Fatwa-Fatwa Jual Beli, Jakarta: Pustaka Imam Syafii.

13 Abdurrahman As Sa'di dkk, (2014) Fiqih Jual Beli: Panduan Praktis Bisnis Syariah, Jakarta: Senayan abadi.

\section{REFERENCES}

Ad Duwaisy, Ahmad bin abdurrozaq, (2011) Fatwa-Fatwa Jual Beli, Jakarta: Pustaka Imam Syafii.

Al-Zuhaili, Wahbah, (2003) Al-Figh Al-Islam wa Adillathu, Damascus: Dar-Al fikr, As Sa'di, Abdurrahman dkk, (2014) Fiqih Jual Beli: Panduan Praktis Bisnis Syariah, Jakarta: Senayan abadi.

Aziz, Rosyid, (2015) Berkah Melimpah Dengan Bisnis Property Syariah, Bogor: AlAzhar Freshzone.

Chamberlain, T., Hidayat, S., \& Khokhar, A. R. (2020). Credit risk in Islamic banking: Evidence from the GCC. Journal of Islamic Accounting and Business Research.

https://www.rumah.com/panduan-properti/ Lima bank kpr dengan suku bunga rendah per januari 2019-2-9574

Kueger, Malte \& Seits Franz. (2017) Costs and benefits of cash and cashless payment instruments Module 2: The benefits of cash. e-book by Fritz Knapp Verlag, Frankfurt.

Kuncoro, NM.Wahyu, (2015) 97 risiko Transaksi Jual Beli Properti, Jakarta: Raih asa Sukses.

Kusuma, Roby Agung, (2017) Untung Maksimal Dari Bisnis Properti, Jakarta: Laksana.

Triono, Dwi Condro, (2017) Ekonomi Pasar Syariah, Yogyakarta: Irtikaz.

Vadillo, Umar, (2005) Bank Tetap Haram: Kritik Terhadap Kapitalisme Sosialisme, dan Perbankan Syariah, Petaling Jaya: Pustaka Zaman.

Wulandari, P., Putri, N. I. S. P., Kassim, S., \& Sulung, L. A, (2016) Contract Agreement Model for Murabahah Financing in Indonesia Islamic Banking. International Journal of Islamic and Middle Eastern Finance and Management. Vol. 9(2): 190-204. 